\title{
2.7 Сучасний ландшафтний компонент в архітектурі житлових комплексів
}

Природа, вірніше, природні форми завжди були першоосновою поняття досконалості та краси, визнавалися їх еталоном. У сучасному місті відчувається брак земельних ресурсів, що веде до виникнення ущільненої та точкової забудови. Екологічна проблема сьогодні стала актуальною в усіх сферах життя людини. Озеленення територій є недостатнім для вирішення проблеми, тому архітектура повинна враховувати екологічну реальність нашого часу і вирішити низки екологічних проблем за допомогою так званої “зеленої архітектури”.

Необхідна людині зелень, яка може бути розміщена на землі, піднімається на вертикальні і горизонтальні площини будинків. Ефект присутності природи та їі багаторівневе розміщення $є$ трендом ландшафтного дизайну та благоустрою міста. Вертикальне озеленення: “зелені” дахи, фасади, балкони, тераси сьогодні можна побачити у різних куточках світу. Зелені стіни стали використовувати в декорації інтер'єрів на початку 21-го століття: офіси, музеї та приватні будинки стали відводити невеликі стіни під висячі сади-оранжереї. Озеленення будинків починають використовувати у своїх проектах багато відомих архітекторів $\mathrm{i}$ декораторів, наприклад, Ренцо Піано та Андре Путман, Р. Хакні, Ф. Хундертвассер, Ральф Хенкок та інші. Зелена будівля - міст, що сполучає природу та рукотворний світ людини. Такий будинок коштує дорожче, але майже завжди окупається економією на рахунках за енергію. Зелений дах будинку не дозволить знехтувати водою, а рослини, що вимагають сонячне світло, можна вирощувати на балконі. Ландшафтна архітектура спирається на взаємовідносини між суспільством та природним світом. Ландшафтна архітектура націлена на:

•функціонально-просторову організацію середовища життєдіяльності людини;

•перетворення ландшафтів при охороні їх природних особливостей;

•естетику зовнішнього благоустрою.

Завданням ландшафтної архітектури вважають: охорону, перетворення (формування) та відновлення (рекультивацію) ландшафтів. 
Відтворення природного середовища стає все більш актуальною задачею для великих житлових кварталів: використання поверхонь фасадів і дахів будівель, розміщення природних компонентів у внутрішніх структурах будівлі 3 поширенням озеленених поверхонь у просторі.

На сьогоднішній день, існує два основних напрямки впровадження ландшафтних та ландшафтно-рекреаційних одиниць у забудову житлового кварталу: ландшафтна організація зовнішніх просторів території біля будинка та використання закритих внутрішніх просторів для ландшафтних утворень. Також використовують різноманітні техніки, що дають змогу створювати окремі об’єкти та споруди, малі архітектурні форми з живих рослин: pooktre, pleaching, “дерева на шпалерах”, арбо-скульптура або “жива скульптура”, арбоархітектура, ботанічна архітектура та багато інших. 3 рослин можна формувати різноманітні арки, альтанки, літні житлові приміщення, меблі, та предмети. Для них не потрібен дорогий інвентар та складні технології, щоб їх створити треба лише фантазія, терпіння та час.

Цікавий приклад такої архітектури проект “Живого храму”, який створив Джуліано Маурі, відомий італійський архітектор, який не дожив до сучасних днів, проте цей храм, що став його останнім проектом, зростає - тобто “самодобудовується” й дотепер (рис.1). Споруда розташована на околиці італійського міста Бергамо біля підніжжя гори Арера, що на Півночі Італії.

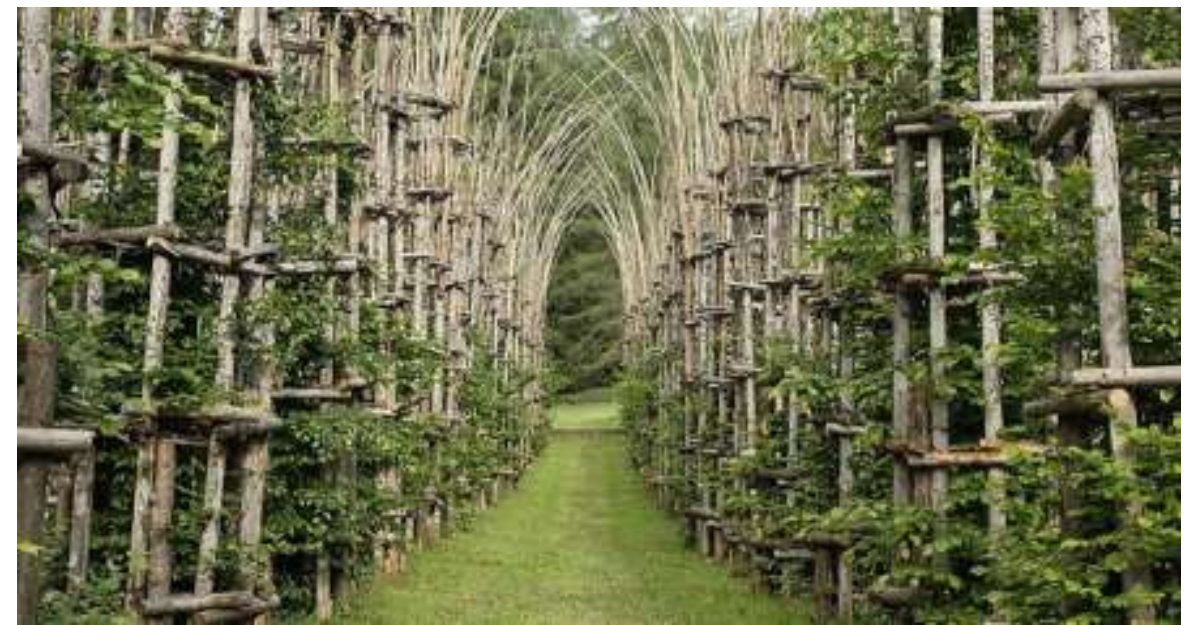

Рис. 1. Житловий храм. Архітектор Джуліано Маурі. 
Суть проекту полягає в тому, що всередині створених із дерева 42-х колон, були посаджені саджанці граба. За задумом Джуліано, приблизно через п’ятнадцять років каркас-колони стануть “тісні” для дерев і природно зруйнуються. А самі граби утворять природну конструкцію справжнього собору з живого дерева. Проект займає значну площу в 650 м (рис. 2).

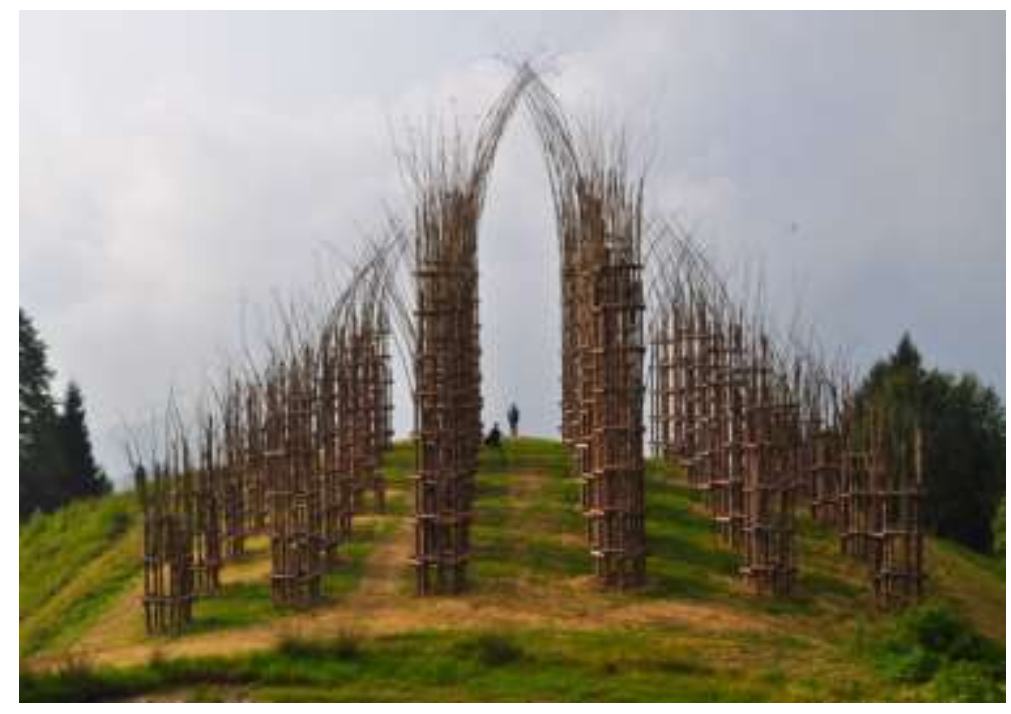

Рис. 2. Житловий храм. Архітектор Джуліано Маурі.

Житловий квартал же вважають багатофункціональною структурою, яка складається із зовнішніх просторів, таких як: двори, дахи, фасади, та внутрішніх - інтер'єри квартир, атріумні простори та інші рекреаційно-функціональні зони. Двір - це перша ланка у зв'язку людського житла із природою. Правильно організоване озеленення території дворів важливе з кількох причин:

- По-перше, зелені насадження сприяють формуванню комфортабельного мікроклімату. Висадка рослин призводить до формування тіні та зменшення швидкості вітру. Також зменшується акустичне навантаження за допомогою зниження рівня шуму.

• По-друге, рослини у дворі нейтралізують значну частину вихлопних газів та інших токсинів, що містяться у повітрі.

- По-третє, озеленення є важливим для формування гармонійного вигляду, оскільки рослинність - це важлива складова ландшафтного дизайну. 
До системи озеленення дворових територій входять сади, зелені насадження на ділянках окремих або груп житлових будівель, озеленені ділянки при школах, дитячих садках, фізкультурних майданчиках та спортивних комплексах. Важлива роль відводиться деревам і чагарникам, що є захисними посадками за межами мікрорайону, вздовж внутрішніх мікрорайонних проїздів, вздовж пішохідних сполучень, навколо господарських споруд, майданчиків сміттєзбірників, гаражів. Зелені насадження прибудинкової території багатоповерхових житлових будинків зазвичай відповідають мінімальним нормативним вимогам.

Японські архітектори розробили систему багатоярусних скверів. Такі композиції ідеально підходять для відпочинку з елементами споглядання. Вони включають декоративні стінки і сходи, тераси і скульптуры, фонтани і водойми. У 1995 році в стилі зеленої архітектури у Фукуоці було збудовано 15-ти поверховий будинок ACROS Fukuoka foundation (Рис. 3). Він і дотепер вважається головною визначною пам'яткою міста. Тут створено конструкцію водовідведення наче вода стікає з гір. Цей метод дозволяє здійснити природне зрощення.

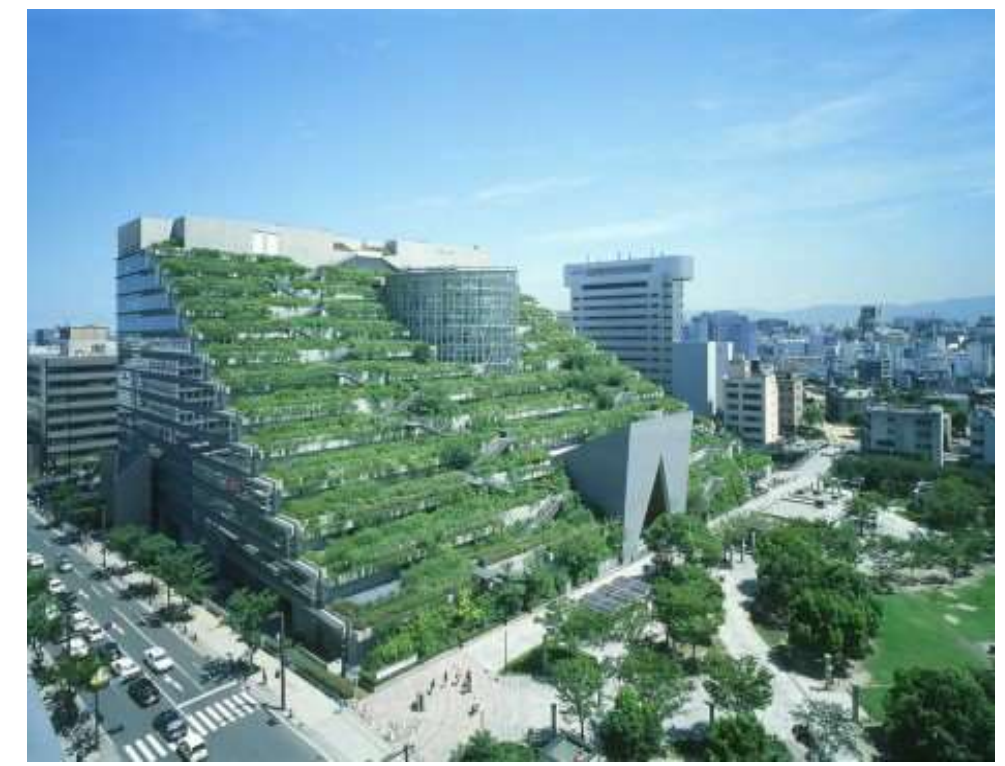

Рис. 3. 15-ти поверховий будинок ACROS, Fukuoka foundation. 
Відвідувачі можуть піднятися зигзагоподібними сходами в сад на верхньому майданчику даху, щоб помилуватися навколишньою природою.

Озеленення балконів та лоджій є поширеним прийомом створення акцентів на поверхні зовнішніх стін. В озелененні балконів з'явилася популярна тенденція висаджування міні-садів та городів.

Озеленення покрівлі — відповідь на виклик поточної кризи недоступності громадських просторів. Сад на даху будинку — це додатковий простір для відпочинку та покращення екологічної ситуації в місті. Зелена покрівля вже давно пропагується як ефективна стратегія з благоустрою зарубіжних будівель для поліпшення якості оточуючого середовища та збільшення інвестиційних можливостей. Система зеленого даху - це використання існуючого даху як додаткового джерела озеленення, який включає високоякісну водозахисну i дренажну систему, фільтрувальну тканину - середовище для вирощування рослин. “Зелене покривало” покращує теплоізоляцію, захищає від дощу, очищає повітря і є заміною зеленим насадженням, які доводиться знищувати заради будівництва споруд. Рослини не тільки виробляють кисень, але і створюють приємну атмосферу у великих просторах, знімаючи стрес і підвищуючи кількість відвідувачів, створюють комфортне і привабливе середовище перебування та проживання.

Живі дахи поділяють на дві групи: екстенсивну (необслуговувану) та інтенсивну (з обов'язковим доглядом). Покрівля екстенсивного типу - це автономна екосистема 3 мінімальним втручанням людини. У завершеному вигляді конструкція являє собою суцільний килим з низькорослих посухостійких рослин. Перевага інтенсивної конструкції - можливість створення унікального ландшафту із місцями відпочинку. Крім декоративного призначення, така покрівля задовольняє тягу людини до землі. Є місця, де попрацювати та відпочити. Цей зелений простір може бути нижче або вище рівня землі, але завжди він існує окремо від землі. Зелені дахи можуть забезпечити широкий спектр суспільних та приватних переваг та успішно використовуються в країнах по всьому світу. Основними перевагами використання зелених дахів є: 
1. Покращена якість повітря.

2. Нові зручні рекреаційні простори.

3. Придушення шуму.

4. Збільшення біорізноманіття.

5. Покращення здоров'я.

6. Помірність ефекту міського теплового острова.

Одними з перших до реалізації цієї ідеї підключилися міланські архітектори: вони вирішили посадити ліс прямо на дахах багатоповерхових будинків. Проект «зеленого хмарочоса» був розроблений в 2011 році. А вже через два роки в місті було завершено будівництво двох величезних хмарочосів, повністю покритих лісом. Житлові будинки Bosco Verticale (рис. 4) вважаються «очисником повітря» Мілана. Вони стали справжнім вертикальним парком в центрі, бо на горизонтальній площині місця для нього вже не було. Будівлі висотою 80 та 111 метрів являють собою два блоки з різноманітною рослинністю, яка розсаджена по фасаду. На думку архітекторів, дерева підвищують вологість повітря, поглинають CO2 і частинки пилу, виділяють кисень, захищають від випромінювання та забруднення, покращуючи якість життя.

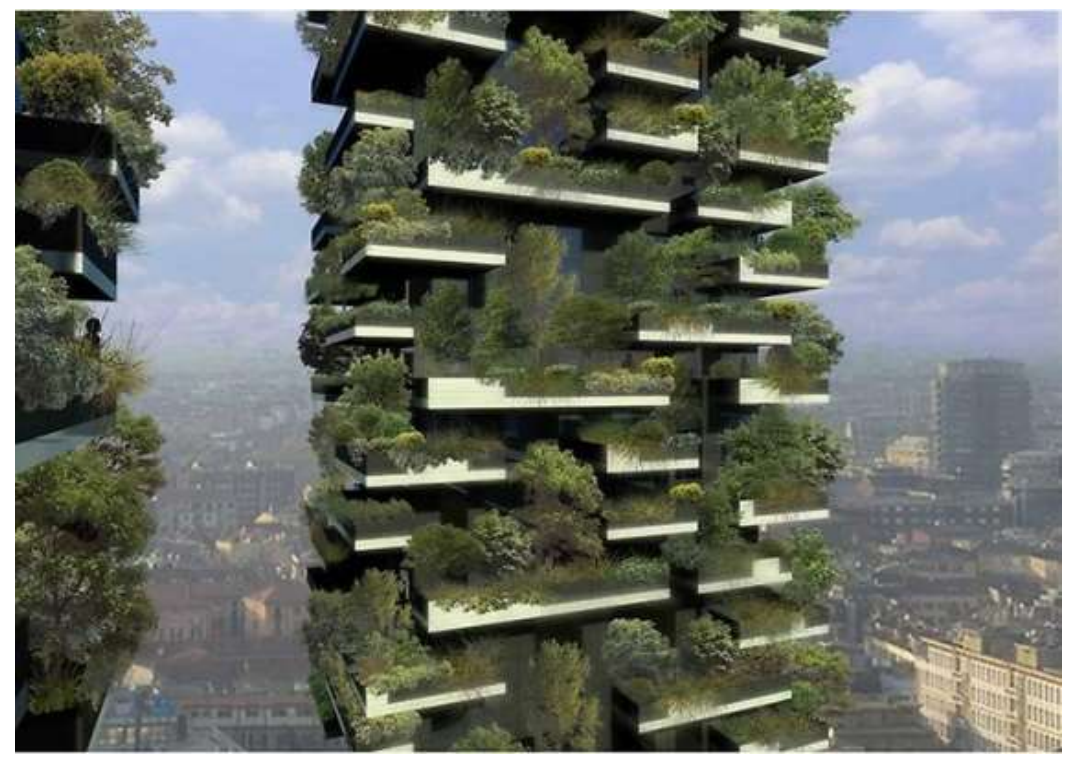

Рис. 4. Житлові будинки Bosco Verticale.

Крім того, така зелена «завіса» не дозволяє проникнути до квартири нестерпній літній спеці, в цей час температура повітря в Мілані досягає 40 градусів 
і вище. Всього на обох будинках посаджено близько 800 дерев, 4 тисяч кущів і 11 тисяч грунтопокривних рослин (рис. 5).

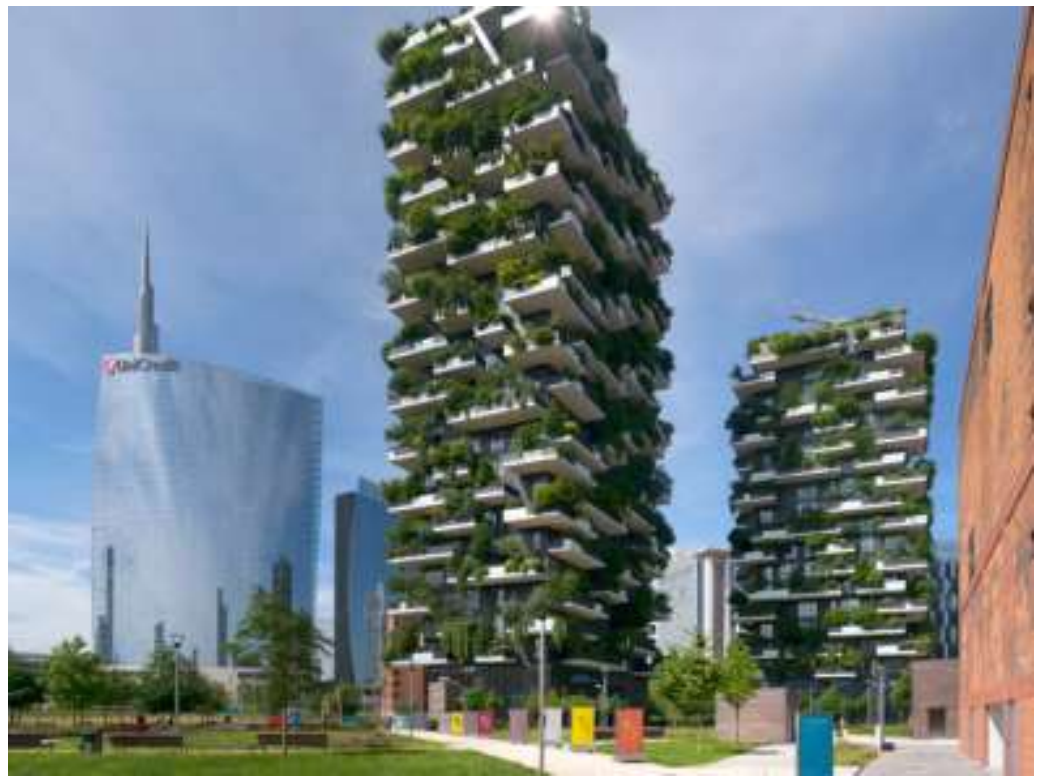

Рис. 5. Житлові будинки Bosco Verticale.

Принципово новий напрямок у фітодизайні - це зелені стіни 3 живих рослин, які можуть застосовуватися як в інтер'єрі, так і в екстер'єрі. Зелені стіни ділять на активні (з грунтом/живильним середовищем) та пасивні (епіфіти мохи, лишайники, папороті). Найбільш розповсюдженими типами сучасних конструкцій зелених стін $є$ модульні системи (панелі із субстратом), килимові системи (з кишенями для рослин) та контейнерні (горщики 3 ампельними рослинами).

За допомогою такого прогресивного методу оформлення житлових квартир можна вирішувати безліч завдань щодо їх благоустрою. Раніше озеленення квартир обмежувалося лише розстановкою рослин у горщиках. Сьогодні в житловому просторі успішно використовуються цілі композиції з живих рослин та квітів. Прямостоячі рослини середньої висоти візуально "піднімають" низькі стелі. Підвішені кашпо - розлогі аналоги - "опускають" надто високі стелі. Велику вітальню за допомогою ступінчастих стелажів з низькорослими та середнього розміру рослинами можна ефектно поділити на кілька функціональних зон. Таке зонування дуже актуально для квартир-студій. Також в інтер'єрах квартир, під'їздах будинків та сходових клітках використовують фіто 
стіни. Цей дизайнерський підхід допомагає покращити якість середовища, в якому перебуває людина.

Таким чином, в результаті розгляду наведених сучасних тенденцій, що застосовуються в озелененні багатоповерхових житлових будівель, можна сформулювати ряд висновків та рекомендацій: 3 підвищенням антропогенного середовища зростає потреба єднання мегаполісів із природою. Стає необхідною інтеграція рослин у структуру житлових споруд для покращення екології та, як наслідок, якості життя людини, сучасні технології дозволяють розміщувати рослини практично у всіх частинах будівлі.

Принцип взаємозв'язку зовнішнього i внутрішнього просторого i природного середовища, на перший погляд, дуже простий. Природа має увійти у внутрішній простір архітектурного об'єкта, а архітектура має вийти у зовнішній простір, створивши поблизу будівлі більш безпечну та комфортну, «окультурену» природу. Завдання розвитку “зеленої архітектури” в проектуванні та будівництві полягає в тому, щоб знайти серед будівель відповідне місце для рослин (як живого матеріалу), котрі будуть приносити користь та красу навколишньому середовищу, створюючи вдале поєднання з архітектурними спорудами, розташовуючись у найвигідніших умовах життя.

“Зелена архітектура” прагне мінімізувати негативний вплив будівництва на природу і надати тільки позитивний вплив на життя теперішніх та наступних поколінь. 